\title{
The Development of Employee Ownership in China
}

\author{
Mygind, Niels; Faigen, Benjamin
}

Document Version

Accepted author manuscript

Published in:

International Journal of Emerging Markets

DOI:

10.1108/IJoEM-12-2015-0261

Publication date:

2017

License

Unspecified

Citation for published version (APA):

Mygind, N., \& Faigen, B. (2017). The Development of Employee Ownership in China. International Journal of Emerging Markets, 12(3), 464-487. https://doi.org/10.1108//JoEM-12-2015-0261

Link to publication in CBS Research Portal

\section{General rights}

Copyright and moral rights for the publications made accessible in the public portal are retained by the authors and/or other copyright owners and it is a condition of accessing publications that users recognise and abide by the legal requirements associated with these rights.

Take down policy

If you believe that this document breaches copyright please contact us (research.lib@cbs.dk) providing details, and we will remove access to the work immediately and investigate your claim. 


\section{The Development of Employee Ownership in China}

\section{Niels Mygind and Benjamin Faigen}

Journal article (Accepted manuscript)

CITE: Mygind, N., \& Faigen, B. (2017). The Development of Employee Ownership in China. International Journal of Emerging Markets, 12(3), 464-487. D0I: 10.1108/IJoEM-12-2015-0261

This article is (0) Emerald Publishing Limited 2017 and permission has been granted for this version to appear here: https://research.cbs.dk/en/publications/the-development-of-employee-ownership-in-china.

Emerald does not grant permission for this article to be further copied/distributed or hosted elsewhere without the express permission from Emerald Group Publishing Limited.

Uploaded to Research@CBS: December २018 


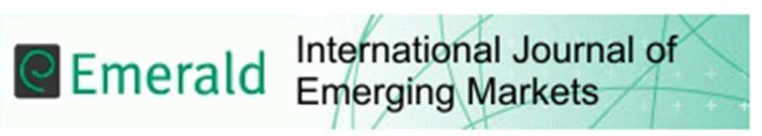

\section{The Development of Employee Ownership in China}

\begin{tabular}{|r|l|}
\hline Journal: & International Journal of Emerging Markets \\
\hline Manuscript ID & IJoEM-12-2015-0261.R1 \\
\hline Manuscript Type: & Research Article \\
\hline Keywords: & employee ownership, Privatization, corporate governance, China \\
\hline \multicolumn{2}{|l}{} \\
\end{tabular}

SCHOLARONE ${ }^{\text {m }}$

Manuscripts 
The development of employee ownership in China

\begin{abstract}
Purpose - Little systematic work has been completed on the incidence of employee ownership in a Chinese context. Similar to the situation in Eastern Europe, this type of ownership was quite widespread in China, particularly during the 1990s. Based on the existing literature and available statistical data the purpose of the paper is to identify drivers of, and barriers to, the development of employee ownership in China. Design/methodology/approach - The scattered evidence from the literature and official statistical sources are collected and structured in a systematic analysis where the drivers and barriers for employee ownership in the transition process from plan to market are identified at three levels; society, the company and the individual. Findings - Employee ownership developed as a transitory stage between state and private ownership; employees acquired ownership stakes as part of the privatization of small- and medium size state-owned enterprises as well as collectively-owned enterprises. However, in most cases the dynamics of ownership resulted in dominant ownership by managers. This trend became more noticeable at later stages of the privatization process. Implications - The paper shows how policies and institutional settings at the society level are determining for the development of employee ownership. Originality/value - The contribution of the paper is to give a general and systematic analysis of the development of employee in China both based on a comprehensive literature review and by utilizing existing statistical sources.
\end{abstract}

Keywords: employee ownership, privatization, corporate governance, China. 


\section{Introduction}

In a context of economic transition, the acquisition by employees of majority stakes in their former publicly-owned workplaces through privatisation is one of the most likely ways in which employee ownership can transpire. Such occurrences have been well documented in the literature in relation to parts of Central and Eastern Europe, as well as the former Soviet Union (e.g. Earle and Estrin, 1996; Nuti, 1997; Uvalic and Vaughan-Whitehead, 1997; Mygind, 2012). Comparatively less studied has been the role of employee share acquisition as a component of the restructuring of publicly-owned firms in China, where both the approach to (Lin et al., 1996; Qian et al., 1999; Liu et al., 2006; Bai et al., 2009) and scale of (Guo and Yao, 2005; Zhu, 2012) transformation make it distinctive among the former command economies.

Two research questions are posed herein. Firstly, what has been the extent of employee ownership in China? Secondly, what have been the drivers of, and barriers to, this type of ownership? The focus is on privatisation as an essential part of the transition process. The openings for employee ownership varied over the different stages of this process, as well as between regions and types of enterprises.

To answer the research questions, the approaches of Wright et al. (2000), Blasi et al. (2003) and Cin et al. (2003) are followed in which the scattered evidence is brought together to provide a general analytical discussion. Rather than introducing new empirical data, the overall contribution of this article is the provision of a comprehensive and systematic coverage of the available evidence related to the existence of employee ownership in China. The key issues behind its development are evaluated and an assessment is made of its current state. Where relevant, comparisons will be made with the development of employee ownership during Eastern European economic transition. Novel drivers and barriers are not expected to be found in a Chinese context, but it is expected that the composition and relative weights of the drivers and barriers will have specific Chinese characteristics.

The literature on employee ownership has, by and large, neglected Asia (Wright et al., 2000; Landau et al., 2007). The Jones and Kato (1995) study on employee ownership in Japan is an exception. In another notable Asian study, however, Wright et al. (2000, p.98) exclude China because 'employee ownership has to be considered in the context of transitions from communist to more capitalistic forms of economic organisation, and hence the evolution of employee share ownership is considerably more complex'. A couple of predecessors to this paper are, nevertheless, notable. Li and Putterman (2008) survey the performance impact which privatisation has had on state-owned enterprises (SOEs) but they do not allocate much attention to the other notable former publicly-owned enterprise form that has undergone transformation, the township and village enterprise (TVE). The majority of China's collectively-owned enterprises (COEs) are made up of TVEs, which are owned by lower levels of government (Jin and Qian, 1998). Zhang and Logue's (2003) employee ownership study comes the closest to this paper in terms of its objectives, but its sources are limited to the date of the study's completion. More than ten years on, important and relevant empirical studies have emerged which warrant inclusion in an investigation of employee ownership in a Chinese context. 
The analysis covers the English-language literature and also includes references to Chinese works. Assistance has been received in covering the Chinese-language literature of relevance, but only a handful of original contributions were found in this process. Concerning the statistics, most of the relevant data from the Statistical Bureau of China are available in English, and help has been received from Chinese speaking assistants for earlier data. For example, the TVE Yearbook, which for the early years is only available in Chinese. Concerning the data on the development of TVEs and other data with specific categories of ownership types, problems concerning coverage and variations in the definitions of specific categories are acknowledged and discussed.

In what follows, the term employee ownership is used to denote a situation where the majority of shares and corresponding rights are held by a broad group of employees. A more precise definition cannot be used because the literature and the statistical evidence are often quite vague concerning: the proportion of equity that is actually owned by employees; the exact distribution between employee owners; and the proportion of non-owning employees. In relation to the aforementioned rights, shareholders typically participate in all three ownership rights: the right to control, the right to the surplus and the right to the firm's wealth. In reality, there can be cases where employees formally possess these rights but where some are appropriated by other groups. For example, when control is executed by a manager. Such cases are subsequently discussed but, in general, a dominant feature of Chinese reform has been the substantial variation between the formal law and its implementation, with further discrepancies over time and between locations. With the above in mind, claiming to be precise in the provided definitions and measurements of employee ownership would be misleading. Instead, a critical stance is taken toward the evidence in the literature and the degrees of employee rights on offer. After all, one of the broader objectives of the paper is to identify long run trends in the development of employee ownership, rather than to provide exact numbers for this ownership form in a given year or within a given location.

The remainder of the paper is organised as follows. First, the theoretical drivers of, and barriers to, employee ownership are presented for societies in transition. This is followed by an overview of the ownership changes which have taken place during the Chinese economic reform period, chronologically, in light of political developments. The available evidence concerning employee ownership connected to privatisation is then synthesised, and the associated trends together with the drivers of, and barriers to, this type of ownership are identified.

\section{The drivers of, and barriers to, employee ownership during economic transition}

The framework developed by Mygind (2012) is utilised to identify and structure the drivers of, and barriers to, employee ownership at the analytical levels of society, the company and the individual. These drivers and barriers are applied to the context of transition from a command to a market economy, involving privatisation. They are presented in figure one. 
[figure one about here]

It is recognised that there are important differences in the transitional process between China and Eastern Europe, for which the framework was originally applied. In the latter, for example, political institutions collapsed and were substituted with more democratic systems, accompanied by a fundamental change in the political power structure, while the Chinese Communist Party (CCP) has continued to monopolise political power. Transition also took place in over-industrialised countries. In contrast, at the commencement of its reforms, China was predominantly an agricultural country. Overall, transition to a market economy occurred relatively quickly in Eastern Europe, while the Chinese transition has been gradual and has occurred over a much longer period.

At the societal level, transition primarily involves the transformation of institutions, such as the change in ownership structure from state ownership to different market-oriented formats. Privatisation can provide opportunities for employee ownership. However, the change to private ownership may also provide opportunities for competing owners. The actual weight of ownership among different stakeholders is determined by the decisions of both central and local governments. There could be strong geographical differences in the institutional framework for developing employee ownership, with support in some locations and obstacles present in others.

A weak corporate governance system with low protection of outside shareholders favours insiders, and is a driver of management ownership. On the other hand, limited access to credit may be a barrier for management takeovers, making it necessary to obtain capital from external investors or from employee owners.

To achieve sustainable employee ownership, it is necessary to have a system for the valuation of shares, as well as the trading of shares among employees both entering and exiting the company. Procedures for trading employee shares can be included in a nation's company law.

Employees may secure their jobs and salaries through contracts and strong unions, or they may acquire ownership to protect their jobs and maximise incomes. Thus, weak unions and a high risk of unemployment may also drive employee ownership.

At the company level, because of collective decision making problems and possible free riding (Hansmann, 1996, Dow, 2003), employee ownership is more likely to be found among firms which are relatively small and contain a homogenous labour force. Large capital per worker requirements is expected to be a barrier to employee ownership, with this type of ownership most feasible in low capital intensity production (Vanek, 1971; Meade, 1972; Putterman, 1988). At the same time, share ownership is a way to bond key employees to the company and is expected to feature in knowledge-based firms in particular.

At the individual level, low income and wealth may hinder employees from becoming owners. On the other hand, the possession of firm-specific human capital may support employee takeovers, especially if alternative employment openings are limited (Blair, 1995). The command economy created 
special conditions in relation to workplace culture, risk-aversion, and attitudes to ownership. Official ideology emphasised collective attitudes and active participation within the workplace and society. However, the ideology often contradicted the actual practice of hierarchical organisations with bottomdown paternalistic management and limited employee participation. Workers tended to develop a passive wage earner mentality rather than a desire for self-governance.

\section{Stages of economic reform and privatisation and political openings for employee ownership as a stepping stone between collective and private ownership}

In contrast to most Eastern European countries, the broader Chinese transition to a market economy, and the privatisation process it has entailed, has been characterised by gradual changes. Political discussions and power struggles only introduced stepwise a market economy featuring private ownership. This gradualism was not part of a master plan. Rather, it was the result of shifting agendas. Institutional changes were first experienced on a limited scale, based on local initiative, and then endorsed for larger parts of the economy. The transformation of small- and medium-size SOEs and COEs provided a window of opportunity for employees to become owners, especially in some locations. Employee ownership was used as one of the 'stepping stones' in the Chinese transition of 'crossing the river by feeling the stones'.

At the start of transition Eastern European countries were overindustrialised and required deep restructuring. They experienced a collapse in production in the early 1990s, accompanied by high unemployment and falling incomes (Mygind, 2012). Therefore, privatisation could not be based on capital contributions from employees. In contrast, the Chinese transition involved a take-off in industrialisation, as well as record high production and income growth.

The Chinese reform process began in 1978 in rural areas. The household responsibility system in agriculture, and the development of the collectively-owned township and village enterprises (TVEs) combined with the dual track price system, gradually freed prices. Politically, it was not possible to commence privatisation at this stage, but TVEs were among the first to experience ownership change. With the granting of increased production autonomy and advantages in contract procurement and access to finance, TVEs grew rapidly and became the core unit for the industrialisation of rural areas. Although formally publicly owned, local entrepreneurs and groups of employees could, in practice, at least in some cases, appropriate control. However, evidence of employee-owned TVEs before they underwent changes in ownership format has not been uncovered in the literature.

Outright private enterprises in urban areas were initially restricted in size to seven employees. By 1983, these could also be established in rural locations. While it was stressed that labour exploitation would not be tolerated, cooperative ventures, which could employ a greater number of workers, were permitted. They were considered to be 'socialist' and part of the collective economy (Whiting, 1999). However, the cooperative format could also be used by private entrepreneurs to expand beyond the 
limits allowed for private enterprises and to enjoy collective enterprise benefits. These became known as 'red hat' collectives.

Pressure for further liberalisation, with regard to the activities of private enterprises, led to the setting up of several experimental zones in which such enterprises, employing greater numbers of employees, could operate. In the $13^{\text {th }}$ party congress in 1987 , a greater role for private enterprise in the Chinese economy was discussed. Cooperatives were seen as a possible solution to the contradictions between public and private ownership. In the same year, the local government of Wenzhou (Zhejiang province) began to feature rural cooperative shareholding enterprises as part of its experimentation with nonpublic ownership. In 1988, the National People's Congress revised the constitution to legitimise private enterprises. However, this change was met by a political counter-reaction and there was an economic rectification campaign between 1989 and 1991. At this time, the CCP stated that private entrepreneurs exploited their employees and that they therefore could not become party members. Wenzhou in particular came under attack for its 'capitalist' practices.

With Deng Xiaoping's southern tour of advanced factories developed with private and foreign capital in 1992, the political pendulum turned back toward market orientation and with it, private ownership. Reforms of the banking system and the corporatisation of SOEs followed. At the same time, advantages for TVEs in the partially reformed economy of the 1980s disappeared. The idea that managers should be owners to limit the governance problem between them and the interests of owners gained ground (Ho et al., 2003).

In the economic reform process, some provinces - especially those around the Yangtze River Delta region-became forerunners with regard to welcoming private enterprises and later privatising SOEs and COEs. Yet, there were large variations both within and between provinces when it came to these developments, dependent on the balance of power between local authorities, managers of local enterprises and employees. Wenzhou, for instance, contained many private enterprises. When it was uncovered that many of these were registering as cooperatives to receive better access to loans and to benefit from lower taxation, central authorities demanded correct re-registration.

Private forms of ownership began to appear in the early 1990s and accelerated after the 15th National Congress in 1997 had formally endorsed a plan for letting the state 'grasp the large and release the small' public enterprises. This became the major privatisation period, lasting for several years, up until around 2004. Already by 1998 though, over $80 \%$ of the SOEs and COEs operating at the county government level or below, typically the smaller enterprises, had been through some form of privatisation. Overall, the number of SOEs in the industrial sector declined from 114,000 in 1996 to 34,000 in 2003 (Garnaut, Song, Tenev and Yao, 2005). It was especially in the first part of this privatisation period, the first half of the 1990s that a window of opportunity for employee owned firms emerged.

Before mass privatisation occurred, SOEs had been facing competitive pressure from a range of different organisational forms. TVEs, for example, had grown rapidly during the early reform period up 
until the mid-1990s. By 1995, they accounted for 128.6 million employees and $27.3 \%$ of industrial production (Yearbook of China's Township and Village Enterprises). Competitive pressure placed on SOEs also came about through the entry of foreign-invested enterprises (FIEs). This process commenced in the 1980s when companies with some degree of foreign ownership were allowed into special economic zones. Gradually, foreign ownership was allowed to spread from provinces on the eastern coast into other sectors and FIEs captured an increasing share of production and employment. The financial losses experienced by SOEs were largely covered by subsidies from the state controlled banking sector. This turned out to be unsustainable, however, with small SOEs in particular ending up having to be privatised.

Political support for private ownership gathered momentum throughout the latter half of the 1990s. This meant that previously imposed operating restrictions were lifted and the conditions for management buyouts improved. The private sector was able to develop both through privatisations as well as de novo firm creation. Whereas TVEs and urban COEs had placed competitive pressure on SOEs up until the mid-1990s, the fast growing private sector placed pressure on COEs thereafter. A hardening of local government budgets pushed them to sell many of their TVEs (Kung and Lin, 2007) and red hat collectives were transferred to private ownership.

However, according to Cheng (2013) this gradual acceptance of private ownership resulting in an increase in management takeovers, MBOs, also provoked some political reactions. From 1997 to early 2003 there was no central government policy for regulation of MBOs and the extent and methods of management practices for taking over the dominant shares caused protest and scandals in many provinces. In March 2003 a pause in MBO practices was proposed by the Ministry of Finance cooling down the management takeover process. Investigations had found examples of undervaluation of company assets and company financing of MBOs and more strict regulation was gradually introduced especially covering the larger SOEs. However, by the end of 2005 SASAC, the State Owned Asset Supervision and Administration Commission, issued a document stating that SOE managers could hold shares of their company, but they could not be involved in making the privatization plan and fixing the price of SOE assets. The emphasis on SOEs in industrial production has been further downgraded since the major privatisation period, so that the state only maintains majority ownership stakes in a number of large strategic enterprises in sectors such as banking, energy, telecommunication and defense. These SOEs are now combined in 120 business groups and are under the supervision of the State Owned Asset Supervision and Administration Commission (SASAC) (Szamosszegi and Kyle, 2011).

\section{China's overlapping ownership forms and vehicles for employee ownership}

Figure two presents a graphical overview of ownership dynamics in Chinese privatisation, with links made to employee ownership. It is notable that there are some overlaps in ownership forms. In the early reform period, SOEs were under the central plan, while COEs were, to a larger degree, subject to the market (Kung and Lin, 2007; Peng et al., 2004). However, both could be under the control of local 
authorities only. Indeed, Chinese ownership structures have tended to be only vaguely defined and it was not until the turn of the millennium that the nation possessed a more precise company law, as well as legislation regarding shareholder rights.

[figure two about here]

SOEs increasingly became subjected to the market, and managers received greater autonomy. Thus, a grey area was created whereby SOEs overlapped with COEs in terms of ownership structure at the local government level, although they took different legal forms. Some firms have shifted legal identity from SOE to COE, and the downward pointing arrow in figure two illustrates this. In reality, the label that is given to a firm depends to a large degree on how it was registered earlier in its history (Jefferson and $\mathrm{Su}, 2006)$.

The overlap between COEs and private firms, as a result of managers wearing the 'red hat', is illustrated as a grey shaded area in figure two. When advantages for COEs in terms of contracts and access to loans gradually disappeared and private ownership became formally accepted, the red hat was typically taken off. With increasing marketisation and privatisation of the economy, there was a gradual shift downward, marked by the arrows on the left-hand side. Formal privatisations are illustrated by the arrows leading to new legal forms on the right-hand side.

From the available evidence, it can be identified that a major vehicle for employees to become owners in Chinese firms was through the transformation of small and medium-size SOEs and COEs into Joint Stock Cooperatives (JSCs). According to Sun (2000; 2002) JSC formally features majority employee share ownership and representative governance. In this sense, the JSC can be considered the closest to more conventional employee ownership forms such as a worker's cooperative (Cao et al., 1999). Nevertheless, the state (at the local government level) has often remained a shareholder when workers and managers have been unable to afford asset purchases alone (Ma, 1998; Vermeer, 1999; Oi, 2005). In addition, the classic cooperative principle of 'one-person-one-vote' has only been adhered to in some cases and for parts of the shares (Lin and Zhu, 2001; Dong et al., 2002). This means that it cannot be neatly concluded that all JSCs had majority employee ownership by a broad group of employees.

With further regard to the distribution and the rights of employee share-owners in a JSC, two types of shares must exist in such an enterprise: one owned by the village and the other by employees. Employee shares are further composed of two parts. One comes from newly invested stakes in the firm. The other comes from assets earlier invested. Shares are allocated based on tenure and rank, in addition to contributions made (Garnaut et al., 2006). Employees have rights to the surplus in the form of dividends but cannot sell shares. When leaving the firm, these shares are returned (Zhang and Logue, 2003).

According to Vermeer (1999) the JSC can be seen as an impossible combination of cooperative and shareholding features. The cooperative characteristics with focus on labour were: non-withdrawable capital stakes, equality, and the democratic principle of one person - one vote. In contrast the 
shareholding features were emphasizing the role of capital with transferable shares, one share - one vote, and management control. These conflicting sides were balanced differently depending on the stage of transition and the specific distribution of power at different locations. JSCs emerged through a combination of deliberate policy experiments by the State Council in the 1980s, as well as through local bottom-up spontaneous privatisation. Their numbers later expanded due to the relaxation of the pre1992 requirement that shares within TVEs were to be distributed mainly to the community rather than to individuals within the firm, meaning that insiders were both permitted and incentivised to participate in ownership. Soon, the use of this ownership form was adopted more fluidly than in the initial experimental stage and JSCs also began to appear in greater numbers as an avenue for the restructuring of SOEs (Sun et al., 1999, Sun, 2000; Zhang and Logue, 2003).

Employee ownership can also be identified in other legal formats, including limited liability and joint stock companies. The latter was intended to be applied more frequently in the restructuring of larger SOEs, rather than smaller SOEs for which the cooperative form was officially preferred (Ma, 1998; Gu, 1999). As was the case with JSCs, experiments towards establishing a joint-stock system also began in the mid-1980s, with employee shares issued in SOEs located in Beijing and Shanghai, becoming the pilots for the system (Walter and Howie, 2001). While share issuance to employees spread in subsequent years, these were typically only minority holdings. They were issued at par value and with fixed dividends, resembling a company based bond (Zhang and Logue, 2003).

Employee ownership has also been notable via the existence of internal employee shares created before a company became listed (Zhang and Logue, 2003). Such shares were typically sold to employees at a significant discount, opening up the possibility for future capital gains. Although the shares were not intended to be traded externally, an illegal market developed. Companies had not usually obtained approval for public share issues and when public stock exchanges were established in Shanghai and Shenzhen in the 1990-1991 period, internal employee shares could not be legally registered for trading. In 1994, the issuance of these shares was banned by the State Council and the category died out (Green, 2004). In general, the regulations for listed companies concerning the trading of employee shares, as a share class, became quite prohibitive after this time. Employee shares fell from an estimate of up to $13 \%$ in 1991 to $2.3 \%$ in 2001 (Walter and Howie, 2001).

Wei, Xie and Zhang (2005) sample 5,284 listed firms between 1991 and 2001 in a study of the relationship between ownership structure and firm value. Employee shares account for only $1.75 \%$ of the total in this study. This is not an uncommon finding among the studies of listed firms and we conclude that share ownership by employees, even if the practice did continue to some extent after 1994, did not result in a substantial amount of shares held by workers.

At this point of the discussion it can be deduced that the JSC format has had the potential to feature majority employee ownership, but more precise evidence for the actual implementation and further development is required. Therefore, the existing literature is delved into more deeply in what follows. 


\section{Employee ownership during Chinese privatisation: A review of the evidence}

This section of the paper begins by reviewing evidence pertaining to the incidence of employee share ownership in China. The discussion then centres on two themes: the stakeholders involved in decentralised privatisation and individual-level factors pertaining to share acquisition, in light of what has been uncovered. In relation to these subject areas, information found within official Chinese statistical sources is considered, alongside original academic contributions - both country-wide surveys as well as smaller and more local studies. The latter are often more detailed. For example, they can cover the nature and evolvement of ownership structures, as well as the processes leading to particular ownership distributions. Such case studies are mainly taken from coastal provinces where economic change has occurred most rapidly and where employee ownership became quite widespread.

\section{Employee shareholding incidence}

Table one reveals some interesting information in regards to the changing weight of different ownership forms as employment providers, as taken from the officially disseminated China Statistical Yearbook. The JSC form, although not defined individually by the National Bureau of Statistics (NBS), is understood to correspond with the official ownership category labelled 'cooperative enterprise'. It must also be stated that Chinese yearbook data relies on firm registration status which may be somewhat troublesome because an enterprise that took on a different corporate form after privatisation may still have been recorded in its original form (Cao et al., 1999). Also, the prevalence of mixed ownership in the economy means that one cannot know with full confidence the true identity of the dominant owner of an enterprise. For instance, what can often appear on the surface to be public ownership may in fact conceal significant informal or hidden privatisation (Jefferson and Su, 2006; Liu et al., 2006).

Urban JSCs employed 1.4 million workers in 1998. It is assumed that most of these JSCs were transformed from urban COEs, which fell steeply over the preceding period. An increasing proportion of COEs became corporatised, or became private firms with management as majority owners. Employment in urban JSCs peaked in 2004 with 1.9 million employees, falling to 1.5 million in 2012. JSCs made up only $0.7 \%$ of urban employment in 2004 , falling to $0.4 \%$ in 2012 .

The bottom line of table one adds employment figures in rural JSCs from the TVE yearbook. Already by 1994, 8 million workers were employed in this type of enterprise, rising to 9.3 million in 2000. In this same period, the data indicates that there were 204,000 rural JSCs in 1994 , falling to 188,000 by 2000. By 2002, there were only 79,000 of these firms remaining, employing 3.7 million workers. Employment in rural JSCs fell again to 2.5 million workers by 2011. Nevertheless, the absolute number of rural JSCs has gradually increased over time so that by 2011 , they numbered $203,000(3.2 \%$ of the number of registered TVEs, not including single person enterprises), contributing $2.8 \%$ and $2.0 \%$ of total employment and output, respectively.

Some further information can be gleaned from the national economic census, conducted in 2004 and 2008 , covering the secondary and tertiary sectors. By the end of 2004, there were 107,000 JSCs. By 
2008 , their number fell to 64,000 , a fall from $3.3 \%$ to $1.3 \%$ of the total number of firms. The proportion of JSCs is slightly higher in manufacturing than in construction and trade. Employment in manufacturing JSCs fell from 2.1 million employees in 2004 to 1.1 million employees in 2008.

[table one about here]

Table two gives an overview over the main empirical evidence first for larger surveys with representative coverage of the whole of China and then follows smaller and more local or regional surveys and some more case oriented studies with lower number of investigated companies. The first mentioned sources by Sun (2000 and 2002) have not contributed with new surveys, but builds on data from TVE Yearbook and the second by Lin \& Zhu, (2001) builds on a large official survey on industrial SOEs performed in 1998. Both are Chinese sources analysed by Chinese academics. The following references in the table have all included new material. For each main scientific contribution the table reveals in the second column the period and geographical areas covered. The third column includes information about the source of the data, including the year(s) of collection and the number and types of firms surveyed. The fourth column focuses on the results in relation to the progress and types of privatisation and indicators for the spread of JSCs. The fifth column focuses on the resulting distribution of ownership on employees and managers, and if specified private outsiders.

[table two about here]

According to Sun (2000 and 2002) the evidence mainly from the TVE-Yearbook indicates that privatisation pervaded rural Chinese industry and significantly transformed TVEs in the collectivelyowned sector. Of the various methods for restructuring TVEs, transformation to JSCs made up a sizeable proportion overall. Specifically, by the end of 2000, out of those TVEs that had undergone complete restructuring, $13 \%$ had converted to the JSC form. Among the 802,000 firms in the TVE sector at this time, there were 163,000 JSCs $(20 \%)$ and 25,000 joint stock companies (3\%). The remaining firms maintained conventional public ownership, with some provisions for managerial autonomy (77\%). Additional studies highlight the contribution of the JSC form to privatisation in rural industry.

The privatisation of SOEs also involved considerable usage of the JSC form (Lin and Zhu, 2001). In a survey of $62 \%$ of industrial SOEs in operation across the country in 1998, JSCs comprised $16 \%$ of those that had been restructured The National Bureau of Statistics performed a survey with responses from $62 \%$ of industrial SOEs in operation across the country in the summer of 1998 that is 40,238 . Of these 6,872 or $17 \%$ had completed restructuring at the time of the survey most of them in 1997 . A representative subsample of 3.150 of the restructured firms was surveyed with focus on ownership changes. $55 \%$ of the restructured enterprises became limited liability companies, $16 \%$ JSC and the rest 
went to private or other forms. Although the JSCs were supposed to have majority insider ownership, in about one-fourth of the JSCs the state held more than $50 \%$ of the shares, and in $20 \%$ of the JSCs had no individual shares held by the employees. In JSCs where employees owned shares, the principle of oneperson one-vote for the collective part of the shares was generally not adhered to, even if regulations dictated otherwise. The JSCs were most frequent among the smaller firms in the sample of SOEs. The top manager owned on average $3.6 \%$ of the shares in the JSCs while in private entities the top manager owned $48 \%$ on average.

In a nationally representative survey of 683 city SOEs conducted in 2002, seven years into the major privatisation period, employee shareholding represented the largest of the various methods utilised to restructure SOEs (Garnaut et al., 2006). Of the 103 employee shareholding cases, the limited liability company form was chosen in 53\% of them and the JSC form was chosen in 34\% of them.

Guo et al 2008 and Gan et al 2010 base their analysis on a comprehensive national survey. A stratified random sample of 11,000 firms was based on the 2004 NBS census containing all industrial firms with sales above 5 million RMB. To focus on privatisation an additional random sample of 5,500 firms from the earlier 1998 NBS survey was added. With a response rate of $18 \%$ the final data included data from 2935 firms including 717 privatised firms, 460 non-privatised SOEs and COEs plus 1758 de novo private firms. The sample turned out to be fairly representative for both regions and industries with a slight overrepresentation of large SOEs. The authors find that MBOs is by far the most frequents type covering about half of privatisations. They label $10 \%$ as employee shareholding and $22 \%$ for direct sale to outsiders, which however in many cases included some state related organisations. In the process the authors have rather asked for intervals for different types of owners instead of asking directly for MBOs which, as mentioned earlier, for some years were quite controversial. Thus, employee shareholding may in earlier studies have been exaggerated related to the "red hat" tendency of avoiding to use the correct labeling of management ownership.

The evidence broadly covering the whole of China points to a considerable role of employee ownership, especially in the JSC format, in the early stages of the privatisation process. However, it also points to the falling importance of this type of ownership over time both in relation to later privatisations and in relation to a change from broader employee to more concentrated ownership by a manager and key employees. These tendencies are often stronger when investigating the literature covering more local cases.

The first strongholds of JSC were in the coastal provinces. Vermeer (1995 and 1999) made some of the earliest studies based on interviews in 36 firms. In the Northern coastal provinces he found strong variation in privatization methods and distribution of shares. At the early stages the local community kept relatively large parts of the ownership, but gradually insiders got a bigger share. Especially, in the period 1992-1995 JSCs were used as a "middle road" between collective and private ownership. 
Whiting (1999 and 2000) also did intensive case-oriented studies based on interviews with different stakeholders involved in the privatisation process in coastal provinces. She has detailed information about Yueqing County in Wenzhou, Zhejiang province where the first experimental shareholding cooperatives emerged already in 1985. In Hualing town, 220 firms out of a total of 275 firms were shareholding cooperatives by 1991 responsible for $71 \%$ of employment and $90 \%$ of output. In Yueqing County, the total number of shareholding companies grew from 2311 in 1985 to 4370 in 1994, employment doubled and by 1994 the cooperatives accounted for $46 \%$ of industrial output (Whiting 2000). The exact ownership distribution is not revealed, but the cooperative format was used as a step toward private ownership dominated by management. Whiting (2000) contrasts the development in Wenzhou with Songjiang in the Shanghai area and Wuxi (Jiangsu), where collective enterprises run by the local authorities in 1994 still covered more than $95 \%$ of production. In contrast to Wenzhou, the local authorities did not use the experiments for opening up for more private ownership. Instead their main purpose was to keep municipal control and gain more capital inputs including stakes from the employees.

In most TVE conversions the cooperative form included only limited control rights for the broad group of employees, since restructuring was predominantly an instrument for managers to take control, whilst maintaining the advantages of collective ownership in relation to taxation and access to loans (Vermeer 1995, 1999; Whiting 1999, 2000).

Cao et al. (1999) not included in the table, builds on a Chinese report by $\mathrm{Lu}$ (1997). Shunde in Guangdong is referred as an example of a very early and successful development of TVEs. This county were also in front in the further privatisation process beginning in 1993. 1083 state and collective enterprises including TVEs were chosen for ownership reform. Of these were 331 changed into stock cooperatives. The report includes an example of broad employee ownership, the "Qianjin Silk Company", a SOE transformed into a JSC with 15 board members owning $12 \%$ of the equity, middle managers $20 \%$ and other employees $68 \%$.

In Zhucheng County in Shandong, most of the SOEs and COEs were transformed to JSCs in 19921994 (Sun 2000). About a third of the TVEs were restructured and most of these were transferred to JSCs. Based on Wu and Ding (1997) Cao et al. (1999) reports that this county starting in 1992 transformed 37 of its 50 SOEs and 32 became cooperatives. One of the rarely reported examples of a fully employee owned JSC was the "Sida Insulation Material Company" where all the 340 employees got all the shares.

Also most of Zhucheng's TVEs were transformed to JSCs. According to Naughton (2003) all the shares went to insiders, however managers received 4-30 times higher stakes than others. Workers had in general to pay $5000 \mathrm{Rmb}$ per share about equal to the annual wage, but both managers and workers had access to fairly generous credits to finance their shares.

Li and Rozelle (2000; 2003) performed two rounds of quantitative surveys supplied with interviews of key stakeholders in Jiangsu and Zhejiang provinces in 1998 and 2000 covering rural industrial firms 
for the period 1993-1999. Their results show a clear dominance of insider takeovers with a high and increasing share of management ownership over time. The first survey of 88 privatised township enterprises (TE) shows a fast privatisation process from 1994 to 1997 where the township ownership share falls from $85 \%$ to $15 \%$ while managers ends up with $48 \%$ and the broad group of employees with $22 \%$. In the following study with a higher number of firms in the survey they document a high variation between counties in the speed of privatisation. Some counties have nearly finished the privatisation by 1999 while others are still in the initial stages. They also document the strong dominance of managers accumulating on average $70 \%$ with other employees only $22 \%$ of the shares in the privatised companies at the end of the observed period.

The study by Dong, Putterman \& Unel 2006 covers a panel of both rural and urban manufacturing enterprises from Nanjing in Jiangsu province for the period 1994-2001. 8\% of the SOEs, $30 \%$ of the urban COEs and $24 \%$ of the TVEs transferred to the JSC format. Both rural and urban enterprises were privatised primarily to insiders. While the investigated 95 privatised TVEs exhibited a rising trend of managerial ownership over the period, the study point to increasing or stable employee ownership in the 70 urban firms investigated, resulting in a roughly equal share of ownership between managers and employees.

The study by Tseo et al., (2004) shows similar tendencies of 12 majority employee owned firms in the city of Zhucheng (Shandong) with average employee ownership stable around $73 \%$, while the manager share increased slightly from $20 \%$ to $25 \%$ over the period 1994-2000. In nearby Qingdao 6 out of 8 investigated majority employee owned enterprises had on average 76\% employee share in 1994 and $67 \%$ six years later. However, in the two other enterprises the managers doubled their shares and got a dominant ownership position.

Oi 2005 has collected data mainly based on interviews with CEOs and accountants over the period 2000-04 supplemented with a survey done 2000-01 for 451 industrial firms in five cities in Jiangsu, Zhejiang, Henan and Guangdong. The survey focused on restructuring done 1994-2000. Different types of shareholding covered 168 of the 305 reported cases of restructuring. Many large SOEs were not restructured, but those privatized went to limited liability shareholding, while medium and small SOEs and COEs to a higher degree took the JSCs format. The employees got most shares in the initial stages. The early forms of restructuring limited the shares managers could buy. In the later stages the trend was to promote the concentration of shares owned by managers.

Taken together these studies show a strong variation in the development both over time and between locations. The regulation related to employee ownership including JSCs and shareholding companies did not follow a clear path, but it was dependent on local experiments and differences in local implementations of central directives. The different stages of developments can be summarized like this: The first stage goes back to the early experiments in the second half of the 1980s primarily in Wenzhou. The second stage in the early 1990s saw quite widespread implementation of JSCs in rural 
areas, and transformations to JSCs and stock shareholding companies in urban areas. However, in these early years there were at some locations limits to the share transferred from local authorities. These restrictions were relaxed in the mid-1990s and the most frequent restructuring was through transfer of the bulk of the shares to insiders. In this period the broad group of employees could get substantial and even majority shares. However, the managers' position may be underreported in this stage because management domination of ownership was only reluctantly accepted by the authorities. Therefore, it can be assumed that de facto management ownership was often hidden under a cooperative format. When management ownership became politically accepted in the end of the 1990s managers could take off the "red hat" and the actual management domination was revealed. The political reaction around 2003 apparently only meant a temporary pause in this trend toward private management ownership, which came to be the dominant ownership format in China. It is impossible to specify the stages more precisely because the actual local implementation caused strong variation between provinces and even between nearby areas. The importance of local political processes and alliances will be further documented in the following subsection.

Several sources point to the fact that JSCs were the most frequent type of transformations of TVE and also frequently used for transformations of small urban collective firms. For larger companies joint stock liability formats were dominating. Most of the smallest companies were taken over by managers as early as the local conditions allowed. However, when the companies passed a certain size a broader group of employees was needed for financing the takeover, and the degree of employee ownership became higher at least for a period.

\section{The process of decentralised privatisation and stakeholder involvement}

Privatisation was a contested process, both in the ex-ante decision regarding share distribution and in the following process often with concentration of ownership in the hands of the managers. Key stakeholders included the government at the central and local levels, alongside managers and employees. The central government, while in the 1990s supportive of share sales to employees, came to favour a highly skewed distribution of shares, with ownership concentrated in the hands of managers (Oi, 2005; Garnaut et al., 2005). This occurred in parallel with the approval of private property rights. At the local government level, meanwhile, bargaining between officials and firm managers had the greatest impact on resulting shareholding distributions (Dong et al., 2002; Zeng, 2010; Sun et al., 2010). The broader employee group was only entitled to the shares not initially allocated to the preferred parties of management and a few key employees. However, managers' fears of a negative reaction to restructuring plans, and, in some cases, rules stipulating approval for firm restructuring from workers (Garnaut et al., 2006; Oi, 2005) led to shareholding becoming a form of compensation for those relinquishing job security, especially in SOEs. As summarised by government officials in Jinhua (Zhejiang province), 'employee ownership satisfied three constraints: government officials' fear of 
making political mistakes, managers' fear of losing power, and workers' fear of losing jobs.' (Tenev et al., 2002, p.32).

Extant evidence, based on local level cases, illuminates the role of stakeholders in determining privatisation outcomes. For example, in 39 TVEs privatised via sales to insiders in three counties of Shandong and Jiangsu provinces, the primary goal for the local authorities was to provide more incentives to managers by making them majority owners (Dong et al., 2002; Ho et al., 2003). Managers received the majority of shares in 33 of them, while employees received the majority in only six. Overall, $77 \%$ of the shares in the privatised TVEs were held by managers, $18 \%$ by other employees and $3 \%$ by local governments, with independent private investors making up the remainder. It appears as if broader employee ownership arose only in those cases where managers either found it too risky to purchase shares, or could not afford the takeover themselves. The latter was particularly common in the larger and more capital-intensive firms. This tendency was observed in all three counties, though broader groups of employees received the highest share in the lower income counties where their capital contributions were most needed for the insider takeover

Differences in privatisation outcomes between Wuxi (Jiangsu province) and Wenzhou (Zhejiang province) in the 1997-2000 period are documented by Zhang (2008). In Wuxi, the local authorities and managers of TVEs shared strong networks with significant influence. Hence, they were the only stakeholders included in the privatisation process. The result was that all 18 observed companies were taken over by managers, often at low prices settled in closed-door negotiations. By contrast, privatisation in Wenzhou, with a relatively weak local government and a stronger private firm presence, involved a higher degree of independence and decentralised initiative. Share distributions were thus more transparent and employees were able to participate in the process.

In summary, the actual distribution of initial ownership stakes depended to a large degree on the specific processes involved and the balance of power between different stakeholders, of which the local government, managers and employees were the most important. An alliance between local authorities and managers would, in the early privatisation stage, lead to the continued involvement of the local government. Later, with changing economic conditions, outright privatisation was implemented and managers could take over enterprises with the consent of local government. However, when financial contributions from employees were required for a takeover, there could be temporary employee ownership until managers could finance a takeover themselves.

\section{Individual resources and motives behind share acquisition}

Throughout the reform period, Chinese workers have experienced steep wage increases and the household savings rate has been high. Thus, many workers have had the financial possibility to acquire shares. This in an important reason why in China employee ownership has generally resulted from direct share purchases, rather than giveaways like the voucher schemes experienced in some countries in Eastern Europe (Mygind, 2012). This brings up motives behind the share purchase decision as an 
area of investigation, since a choice must be made by a given individual with regard to purchasing shares and thus becoming an employee owner, or remaining a wage earner instead. Empirical studies of employee share ownership at the individual level are rare. One notable exception, however, is the investigation completed by Dong et al., (2002) in which the main motives behind share purchases were found to be financial gains and job security, as opposed to desires for greater control of the workplace. Specifically, $46 \%$ of shareholders expressed the desire to make a financial gain, and $42 \%$ claimed that they wanted to help their firms, a sizeable number for whom a defensive motive to secure employment appeared to be important. Only a small proportion of non-shareholders claimed that they lacked the personal finance to purchase shares, indicating that low individual income and wealth was not a barrier to employee ownership. Indeed, the vast majority of non-shareholders in this case claimed that their main reason for not purchasing shares was simply that they had not received the opportunity.

Often employees viewed shareholdings favourably as a means of enhancing job security (Tenev et al., 2002; Tseo et al., 2004). But also negative reactions toward share offers are reported in the literature. For instance, Kung (1999) writes that attempts to introduce employee shareholding were unsuccessful in Shengfeng village in Jiangsu since workers perceived managers as untrustworthy and viewed investments as financially unattractive. A similar reluctance by employees to purchase shares is found by Yao (2004) in relation to Shunde city in Guangdong, while employee shareholding as an overall restructuring method was no longer welcomed toward the end of the privatisation period, with loss-making firms in particular struggling to entice employees to purchase shares (Oi, 2005).

Workers have not always been found to purchase shares out of their own free will. In a review of the documented evidence on 640 firms, workers were found to have been forced to purchase shares in $63 \%$ of the cases (Cheng, 2013). Meanwhile, in a case study of a firm with more than 700 employees, which had undergone ownership reform in 1998, workers were required to purchase shares valued at a minimum of $5000 \mathrm{Rmb}$ (800 USD). Around 100 workers refused to purchase shares, and they were laid off or fired (Cai, 2002). Additionally, in Jiangxi province, workers were given a maximum of 10 days to purchase shares in order to save their jobs and prevent the forfeiting of their pension and welfare benefits (Lau, 1999).

In contrast to the case in the transition in Eastern Europe the broad group of workers were in China often involved in ownership because they could contribute with their savings and at the same time they were needed in cases where managers and top employees could not finance the takeover by themselves. Often the employees were under strong pressure to buy shares not to risk losing their job. In some though limited number of researched cases where they actually could make a choice the dominating motives was job security and to get a good return on their investment. To participate in decision making had a lower rank in the responses from the employees. 


\section{The drivers of, and barriers to, employee ownership in China}

The drivers of, and barriers to, employee ownership in China are summarised in figure three. At the societal level, the primary driver behind the development of employee ownership was the gradual change in the institutional framework, which stepwise opened up for market forces and private ownership. In this process, the transformation of small and medium-size SOEs and COEs provided a window of opportunity for employees to become owners. Urban COEs and rural TVEs were the stepping stones for market-oriented industrialisation. It was especially in the further conversion of these enterprises that employee ownership played a role. The collective format functioned as a transitory stage between state and private ownership and the JSC was a stepping stone between collective and private ownership. In Eastern Europe the openings for employee ownership had a slightly different role. It could be considered as giving the assets back to workers who in most cases received ownership stakes in their enterprises without paying substantial amounts in return like in China. However, in both cases ultimately the ownership ended up in the hands of managers.

There is still a way to go in relation to developing corporate governance institutions, the judiciary for law enforcement, and the financial system in China. Insiders are in a strong position compared to external owners, while managers have a dominant position in relation to all other owners including employee owners. They have had the scope for channeling economic value into their own pockets. Indeed, in most cases, managers have dominated the transformation of smaller SOEs and COEs. The evidence indicates that most enterprises already contained majority management ownership at the outset of the major privatisation period in the end of the 1990s and that the share of management ownership increased further over time. Independent external investors were rare in the insider-dominated privatisation process. It is apparent that a weak corporate governance system, featuring only limited protection of minority shareholders and a lack of transparency has made it difficult for external investors to monitor investments, especially in non-listed small and medium-sized enterprises. With the prevalence of insider ownership and increasing management ownership, the Chinese ownership cycle largely follows the pattern evident in most parts of Eastern Europe.

An important vehicle for employee ownership was the JSC, a form which received initial political support and was experimented with as early as the 1980s. In rural areas, this form had its golden period in the mid- 1990s, providing at one time around 7\% of total rural employment. Some of these firms featured majority ownership by a broad group of employees, but in many JSCs only managers and a few key employees became owners. Indeed, the JSC format was generally an instrument for management buyouts rather than a genuine attempt at developing broad-based employee ownership. Eventually, political support turned toward private ownership. Previous advantages that could be obtained from being connected to the collective sector were taken away and many JSCs including 'red hat' collectives were transformed to private ownership forms. Like in Eastern Europe there was no legal framework to secure sustainable employee ownership structures. 
The frequency of management takeovers, the role played by JSCs, and the involvement of the broad group of employees in ownership varied strongly over time and by location. Developments were subject to central government influence, the possibilities and conditions for local experimentation, and the balance of power between different groups at the local level. An alliance between local authorities and managers often secured buyouts with employee participation only to the extent it was needed to help finance a takeover. In some cases, employees were formally required to approve privatisation plans and, at the same time, their benefits connected to earlier public ownership forms, especially in SOEs, were given up. Hence, these benefits related to secure wages and pensions could be 'traded' for employee shares.

In the early 1990s, there were examples of joint stock companies featuring employee shares, some of which were listed on the nascent stock exchanges, but instances of such companies were rare and the issuing and trading of such employee shares later became restricted. Today, employee shares make up only a negligible part of the share capital in listed companies.

Throughout the privatisation process, the risk of unemployment was ever-present. It was an overall concern of local authorities to avoid large-scale worker lay-offs, in relation to both economic growth and political stability. Hence, there was an overlap of interests between employees and local authorities, and such an alliance may have played a role in promoting employee ownership to help stabilise employment. However, the continued rise of the non-state sector can be seen to have provided sufficient employment opportunities for job seekers, largely limiting the need for employees to become enterprise owners and potentially the desirability of doing so.

Unions in China, meanwhile, can be considered a direct instrument of the CCP and the literature does not provide any examples of them playing a proactive role in relation to employee ownership

At the company level, the JSC was utilised in the transformation of mainly small and medium-sized companies. The joint stock company, connected to the restructuring of large firms, was of less importance, with only minority employee shareholdings. Managers were able to take over the smallest and cheapest companies themselves. To take over medium sized enterprises with higher capital requirements, managers required the contributions of the broader employee group. Thus, employee ownership appeared in the relatively more capital-demanding enterprises, contrary to theoretical prediction and the Eastern European experience. The largest and most capital-intensive enterprises are still mainly state-owned, and, with few exceptions, they do not contain considerable levels of employee shareholding.

Human-capital dependent firms had been predicted to contain employee ownership as a bonding mechanism for key employees. These types of firms, a handful of which feature employee ownership, are conspicuous today in the knowledge intensive part of the service sector, such as consulting, IT and the media, despite still lagging behind manufacturing firms. In the transition stage, which featured the pronounced selling off of publicly owned enterprises, this article's focal point, such firms were less 
commonly found. Like in Eastern Europe advanced market oriented services within finance, consulting, marketing etc. did not exist in the command economy and therefore not part of the privatisation process.

The drivers of, and barriers to, employee ownership at the individual level have some specific Chinese characteristics. This is especially the case with regard to income growth. Contrary to the situation in Eastern Europe, Chinese employees have experienced increasing incomes during the privatisation period. In addition, households have considerable savings. Therefore, they have possessed the ability to invest in their enterprises (without necessarily needing favourable provisions in privatisation design), and this has been important for the development of employee ownership. There are many examples of broad groups of employees having invested considerable amounts exceeding their yearly pay.

Protection of jobs was frequently reported as an important motive for employees to be involved in ownership. There are cases of direct pressure being placed on employees to contribute their savings in order not to lose their jobs. When they possessed unconstrained choice in terms of whether or not to purchase shares, the limited evidence points to the opportunity to achieve a capital gain and job security as the main motives driving employee ownership, rather than a genuine desire to participate in control.

[figure three about here]

\section{Conclusion and perspectives}

This article has provided an overview of the existing data and literature, and concluded that employee ownership in China, like in Eastern Europe, has been a transitory phenomenon. It was used in China as an intermediate point, between state and private ownership as the prevailing political climate was not initially conducive to fully embracing the latter. Indeed, at the societal level, institutional changes were directed toward a gradual opening up for market forces. Employee ownership became "one of the stepping stones in crossing the river" in the transition toward an economy with increased private ownership. The format of the JSC played an especially important role, most prominently in the mid1990s in rural areas. However, when further steps were taken toward an acceptance of private ownership, most JSCs were transferred over to managers. This process varied both with specific implementation at the local level and with firm-level conditions.

At the company level: large enterprises were mostly transformed to shareholding companies with only limited employee ownership, while small and medium-sized enterprises more frequently had a substantial element of employee ownership. Contrary to theoretical predictions and to the experience in Eastern Europe, more capital intensive companies were within the reach of employee ownership. Managers simply needed employees as suppliers of capital.

At the individual level, broad groups of employees in China have had considerable savings ready to be invested in their companies. However, for the individual employee, the limited evidence indicates 
that the main motives for being owners were job security and a return on investment while the desire for control was not a widespread motive.

It can be deduced that the opportunities for individual share ownership have been principally tied to institutional developments. Employees can be seen to have been brought in as owners largely as a matter of convenience. JSC employment has fallen in recent times, limiting the opportunities for ownership to those who may desire it as a collective alternative to wage employment. Yet, ownership, when it was available, was generally not perceived as attractive for its collective properties. Rather, it was viewed in instrumental terms, a partial reflection of a societal trend legitimising private wealth accumulation and personal advancement.

Like in many Eastern European countries, employee ownership was used in China as an intermediary stage between state and private ownership because the political conditions was not ready for taking the full step toward the latter in the early stages of transition. For the few remaining countries with widespread state ownership such as North Korea, Cuba and Venezuela, employee ownership could play a similar role in possible future transition processes as it has in China.

However, instead of only being a transitory ownership format, it could have a more enduring role. As emerging economies become more advanced, there is scope to introduce legislation concerning tax advantages and financial opportunities to promote the more widespread use of employee ownership. Supporting institutions for cooperatives are evident in Spain, Italy and France and for ESOPs in the United States. With regard to the latter, employee ownership ends up being utilised as a motivational tool and for aligning the interests of employees with employers, especially in knowledge intensive companies dependent on human capital. 


\section{References}

Bai, C-e., Lu, J. and Tao, Z. (2009), "How does privatization work in China?", Journal of Comparative Economics, Vol. 37 No. 3, pp. 453-70.

Blair, M.M. (1995), Ownership and control: rethinking corporate governance for the twenty-first century, Brookings Institution, Washington, D.C.

Blasi, J., Kruse, D., Sesil, J. and Kroumova, M. (2003), "An assessment of employee ownership in the United States with implications for the EU", The International Journal of Human Resource Management, Vol. 14 No. 6, pp. 893-919.

Cai, Y. (2002), "The Resistance of Chinese Laid-Off Workers in the Reform Period", The China Quarterly, Vol. 170 No. 2, pp. 327-44.

Cao, Y., Qian, Y. and Weingast, B.R. (1999), "From federalism, Chinese style to privatization, Chinese style", Economics of Transition, Vol. 7 No. 1, pp. 103-31.

Cheng, X. (2013), "The self-empowered new master at the workplace: privatization in Russia and China", unpublished doctoral dissertation, Princeton University, January.

Cin, B., Han, T. and Smith, S.C. (2003), "A tale of two tigers: employee financial participation in Korea and Taiwan", The International Journal of Human Resource Management, Vol. 14 No. 6, pp. 920-41.

Dong, X-y, Bowles, P. and Ho, S.P.S. (2002), “The Determinants of Employee Ownership in China's Privatized Rural Industry: Evidence from Jiangsu and Shandong", Journal of Comparative Economics, Vol. 30 No. 2, pp. 415-37.

Dong, X-y, Bowles, P. and Ho, S.P.S. (2002b), "Share Ownership and Employee Attitudes: Some Evidence from China's Postprivatization Rural Industry", Journal of Comparative Economics, Vol. 30 No. 4, pp. 812-35.

Dong, X-y, Putterman, L. and Unel, B. (2006), "Privatization and firm performance: A comparison between rural and urban enterprises in China", Journal of Comparative Economics, Vol. 34 No. 3, pp. 608-33.

Dow, G.K. (2003), Governing the Firm: Workers' Control in Theory and Practice, Cambridge University Press, West Nyack.

Earle, J.S. and Estrin, S. (1996). "Employee ownership in transition", in: Frydman, R., Gray, C.W. and Rapaczynski, A. (Eds.), Corporate Governance in Central Europe and Russia. Volume 2: Insiders and the State. Central European University Press, Budapest, pp. 1-61.

Gan, J., Guo, Y. and Xu, C. (2010), "Privatization and the Change of Control Rights: The Case of China", working paper no. E-2010-06-006, School of Economics, Peking University, June 17.

Garnaut, R., Song, L., Tenev, S. and Yao, Y. (2005). China's ownership transformation: Process, outcomes, prospects, The International Finance Corporation and the International Bank for Reconstruction and Development/The World Bank, Washington, D.C.

Garnaut, R., Song, L. and Yao, Y. (2006), "Impact and significance of state-owned enterprise restructuring in China", The China Journal, Vol. 55, pp. 35-63.

Green, S. (2004), “The privatisation two-step at China's listed firms", working paper 3, Chatham House. 
Guo, K. and Yao, Y. (2005), "Causes of privatisation in China. Testing several hypotheses", Economics of Transition, Vol. 13 No. 2, pp. 211-38.

Guo, Y., Gan, J, and Xu, C. (2008), “A nationwide Survey of Privatized Firms in China”, Seoul Journal of Economics, Vol. 21 No. 2, pp. 311-31.

Gu, M. (1999), "The Joint Stock Cooperative Enterprise: A New Independent Legal Entity in China" Hastings International and Comparative Law Review, Vol. 125, pp. 125-48.

Hansmann, H. (1996), The Ownership of Enterprise, Harvard University Press, Cambridge and London.

Ho, S.P.S., Bowles, P. and Dong, X-y. (2003), "Letting Go of the Small: An Analysis of the Privatisation of Rural Enterprises in Jiangsu and Shandong", The Journal of Development Studies, Vol. 39 No. 4, pp. 1-26.

Jefferson, G.H. and Su, J. (2006), "Privatization and restructuring in China: Evidence from shareholding ownership, 1995-2001", Journal of Comparative Economics, Vol. 34 No. 1, pp. 146-66.

Jin, H., and Qian, Y. (1998), "Public Versus Private Ownership of Firms: Evidence from Rural China”, The Quarterly Journal of Economics, Vol. 113 No. 3, pp. 773-808.

Jones, D.C. and Kato, T. (1995), "The Productivity Effects of Employee Stock-Ownership Plans and Bonuses: Evidence from Japanese Panel Data." American Economic Review, Vol 85 No. 3, pp. 391-414.

Kung, J.K-S. (1999), "The Evolution of Property Rights in Village Enterprises: The Case of Wuxi County", in: Oi, J.C. and Walder, A.G. (Eds.), Property Rights and Economic Reform in China. Stanford University Press, Stanford, pp. 95-120.

Kung, J.K-S. and Lin, Y-M. (2007), “The Decline of Township-and-Village Enterprises in China's Economic Transition”, World Development, Vol. 35 No. 4, pp. 569-84.

Landau, I., Mitchell, R., O’Connell, A. and Ramsay, I. (2007), “Employee Share Ownership: A Review of the Literature. Employee Share Ownership Project", research Report, Centre for Employment and Labour Relations Law and The Tax Group, The University of Melbourne, March.

Lau, W.K. (1999), "The 15th Congress of the Chinese Communist Party: Milestone in China's Privatization”, Capital \& Class, Vol. 23 No. 51, pp. 51-87.

Li, W. and Putterman, L. (2008), "Reforming China’s SOEs: An Overview”, Comparative Economic Studies, Vol. 50 No. 3, pp.353-80.

Li, H. and Rozelle, S. (2000), "Saving or stripping rural industry: an analysis of privatization and efficiency in China", Agricultural Economics, Vol. 23 No. 3, pp. 241-52.

Li, H. and Rozelle, S. (2003), "Privatizing Rural China: Insider Privatization, Innovative Contracts and the Performance of Township Enterprises", The China Quarterly, Vol. 176, pp. 981-1005.

Lin, J.Y, Cai, F. and Li, Z. (1996), “The Lessons of China's Transition to a Market Economy”, Cato Journal, Vol. 16 No. 2, pp. 201-31

Lin, Y-m. and Zhu, T. (2001), “Ownership Restructuring in Chinese State Industry: An Analysis of Evidence on Initial Organizational Changes”, The China Quarterly, Vol. 166, pp. 305-41.

Liu, G.S., Sun, P. and Woo, W.T. (2006), “The Political Economy of Chinese-Style Privatization: Motives and Constraints", World Development, Vol. 34 No. 12, pp. 2016-33. 
Lu, L. (1997), "Shunde: Transformation of Government Function Based on Property Rights Reform", in: "Realistic Choice: Preliminary Summary of the Practice of Reforming Small State-Owned Enterprises", China Reform and Development Report, Shanghai: Far East Publishing House.

Ma, S.Y. (1998), "The Chinese Route to Privatization: The Evolution of the Shareholding System Option”, Asian Survey, Vol. 38 No. 4, pp. 379-397.

Meade, J.E. (1972), "The Theory of Labour-managed Firms and Profit Sharing", Economic Journal, Vol. 82 No. 325 , pp. 402-28.

Mygind, N. (2012), "Trends in employee ownership in Eastern Europe”, The International Journal of Human Resource Management, Vol. 23 No. 8, pp. 1611-42.

Naughton, B. (2007), The Chinese Economy: Transitions and growth. The MIT Press, Cambridge and London.

Nuti, D.M. (1997), "Employeeism: Corporate Governance and Employee Share Ownership in Transitional Economies", in Bléjer, M.I. and Skreb, M. (Eds.), Macroeconomic stabilization in transition economies, Cambridge University Press, Cambridge, pp. 126-154.

OECD. (2011), Corporate Governance of Listed Companies in China, Paris.

Oi, J.C. (2005), "Patterns of Corporate Restructuring in China: Political Constraints on Privatization", The China Journal, Vol. 53, pp. 115-36.

Peng, M.W., Tan, J. and Tong. T.W. (2004), "Ownership Types and Strategic Groups in an Emerging Economy", Journal of Management Studies, Vol. 41 No. 7, pp. 1105-29.

Putterman, L. (1988), "The firm as association versus the firm as commodity: Efficiency, rights, and ownership", Economics and Philosophy, Vol. 4 No. 2, pp. 243-66.

Qian, Y., Roland, G. and Xu, C. (1999), "Why is China different from Eastern Europe? Perspectives from organization theory", European Economic Review, Vol. 43 No. 4, pp. 1085-94.

Statistical Yearbook of China. (2011), China Statistical Press, Beijing.

Sun, L. (2000), “Anticipatory Ownership Reform Driven by Competition: China's Township-Village and Private Enterprises in the 1990s", Comparative Economic Studies, Vol. 42 No. 3, pp. 49-75.

Sun, L. (2002), "Fading out of local government ownership: recent ownership reform in China's township and village enterprises", Economic Systems, Vol. 26 No. 3, pp. 249-69.

Sun, L., Gu, E.X. and McIntyre, R.J. (1999), The Evolutionary Dynamics of China's Small-and Medium-Sized Enterprises in the 1990s, Vol. 14, UNU World Institute for Development Economics Research.

Sun, P., Wright, M. and Mellahi, K. (2010), "Is Entrepreneur-Politician Alliance Sustainable During Transition? The Case of Management Buyouts in China", Management and Organization Review, Vol. 6 No. 1, pp. 101-21.

Szamosszegi, A. and Cole, K. (2011), An Analysis of State Owned Enterprises and State Capitalism in China, U.S.-China Economic and Security Review Commission, Washington, D.C.

Tenev, S., Zhang, C. and Brefort, L. (2002), Corporate Governance and Enterprise Reform in China. Building the Institutions of Modern Markets. The World Bank and the International Finance Corporation, Washington, D.C. 
Tseo, G.K.Y., Sheng, H.G., Peng-zhu, Z. and Lihai, Z. (2004), "Employee Ownership and Profit Sharing as Positive Factors in the Reform of Chinese State-Owned Enterprises", Economic and Industrial Democracy, Vol. 25 No. 1, pp. 147-77.

Uvalic, M. and Vaughan-Whitehead, D. (1997), "Introduction: Creating employee capitalism in Central and Eastern Europe", in: Uvalic, M. and Vaughan-Whitehead, D. (Eds.), Privatization surprises in transition economies, employee-ownership in Central and Eastern Europe, Edward Elgar, Cheltenham, pp. $1-48$.

Vanek, J. (1971), The Labour Managed Economy: Essays, Cornell University Press, Ithaca, NY.

Vermeer, E.B. (1995), "Experiments With Rural Industrial Shareholding Cooperatives: The Case of Zhoucun District, Shandong Province”, China Information, Vol. 10 No.3-4, pp. 75-107.

Vermeer, E.B. (1999), "Shareholding Cooperatives: A Property Rights Analysis", in: Oi, J.C. and Walder, A.G. (Eds.), Property Rights and Economic Reform in China, Stanford University Press, Stanford, pp. 123-44.

Walter, C.E. and Howie, F.J.T. (2001), 'To Get Rich is Glorious!': China's Stock Market in the '80s and '90s, Palgrave, New York.

Wei, Z., Xie, F., Zhang, S., 2005. Ownership Structure and Firm Value in China's Privatized Firms: 1991-2001. The Journal of Financial and Quantitative Analysis, 40(1): 87-108.

Whiting, S.H. (1999), “The Regional Evolution of Ownership Forms: Shareholding Cooperatives and Rural Industry in Shanghai and Wenzhou", in: Oi, J.C. and Walder, A.G. (Eds.), Property Rights and Economic Reform in China, Stanford University Press, Stanford, pp. 171-200.

Whiting, S.H. (2000), Power and wealth in rural China: the political economy of institutional change, Cambridge University press. New York.

Wright, M., Pendleton, A. and Robbie, K. (2000), "Employee ownership in enterprises in Africa and Asia”, The International Journal of Human Resource Management, Vol. 11 No. 1, pp. 90-111.

Wu, T and Ding, F. (1997), “ Zhucheng: Small SOE Reform Based on Stock Co-operatives”, in: "Realistic Choice: Preliminary Summary of the Practice of Reforming Small State-Owned Enterprises", China Reform and Development Report, Shanghai: Far East Publishing House.

Yao, Y. (2004), "Privatising the small SOEs", in: Garnaut, R. and Song, L. (Eds.), China's Third Economic Transformation: The rise of the private economy, RoutledgeCurzon, London and New York, pp. 91-101.

Yearbook of China's Township and Village Enterprises (1995-2011), China Agriculture Press, Beijing.

Zeng, J. (2010), "Political Compromises: The Privatization of Small- and Medium-Sized Public Enterprises in China”, Journal of Chinese Political Science, Vol. 15 No. 3, pp. 257-82.

Zhang, J. (2008), “State Power, Elite Relations, and the Politics of Privatization in China's Rural Industry: Different Approaches in Two Regions", Asian Survey, Vol. 48 No. 2, pp. 215-38.

Zhang, G. and Logue, J. (2003), “Employee Ownership Chinese Style”, working paper, Ohio Employee Center.

Zhu, X. (2012), “Understanding China's Growth: Past, Present, and Future”, Journal of Economic Perspectives, Vol. 26 No. 4, pp. 103-24. 
Figure 1

Employee ownership: predictions of drivers and barriers for societies in transition

\section{$\underline{\text { Societal level }}$}

1. Institutions supporting employee ownership (local variation can be expected):

a) Some privatisations provide opportunities for a specific period and for specific types of firms

b) Drivers for employee takeovers must be weighed against drivers for MBOs

c) Under-development of the financial system increases demand for more owners as capital providers

d) Specific alliances between different social groups drive different ownership types

e) Weak corporate governance institutions may favour insiders, especially management ownership

\section{Rules for entry/exit of employee owners:}

Rules promote sustainable broad-based and equitable employee ownership, including rules for entry and exit of employee owners. Expect variation in the efficiency of implementation

\section{Labour market: risk and conditions for unemployment:}

The risk of unemployment and poor wage-earning conditions promote employee ownership

\section{Company level}

1. Collective decision problem increases with size, diverse labour, organisational complexity:

Employee-owned firms tend to be relatively small and feature a homogenous workforce, subject to the advantages made available in certain firm types during privatisation

\section{Capital intensity of the firm:}

Employee ownership less likely in capital-intensive firms

\section{Knowledge intensity of the firm:}

Knowledge-based firms benefit from the bonding of firm-specific human capital to the firm

\section{$\underline{\text { Individual level }}$}

\section{Employee resources:}

Low employee income and wealth a barrier for employee takeovers

\section{Desire for self-governance:}

The desire for self-governance is a driver; a wage-earner mentality/culture is a barrier 
Figure 2

Major ownership forms and links to employee ownership in Chinese privatisation

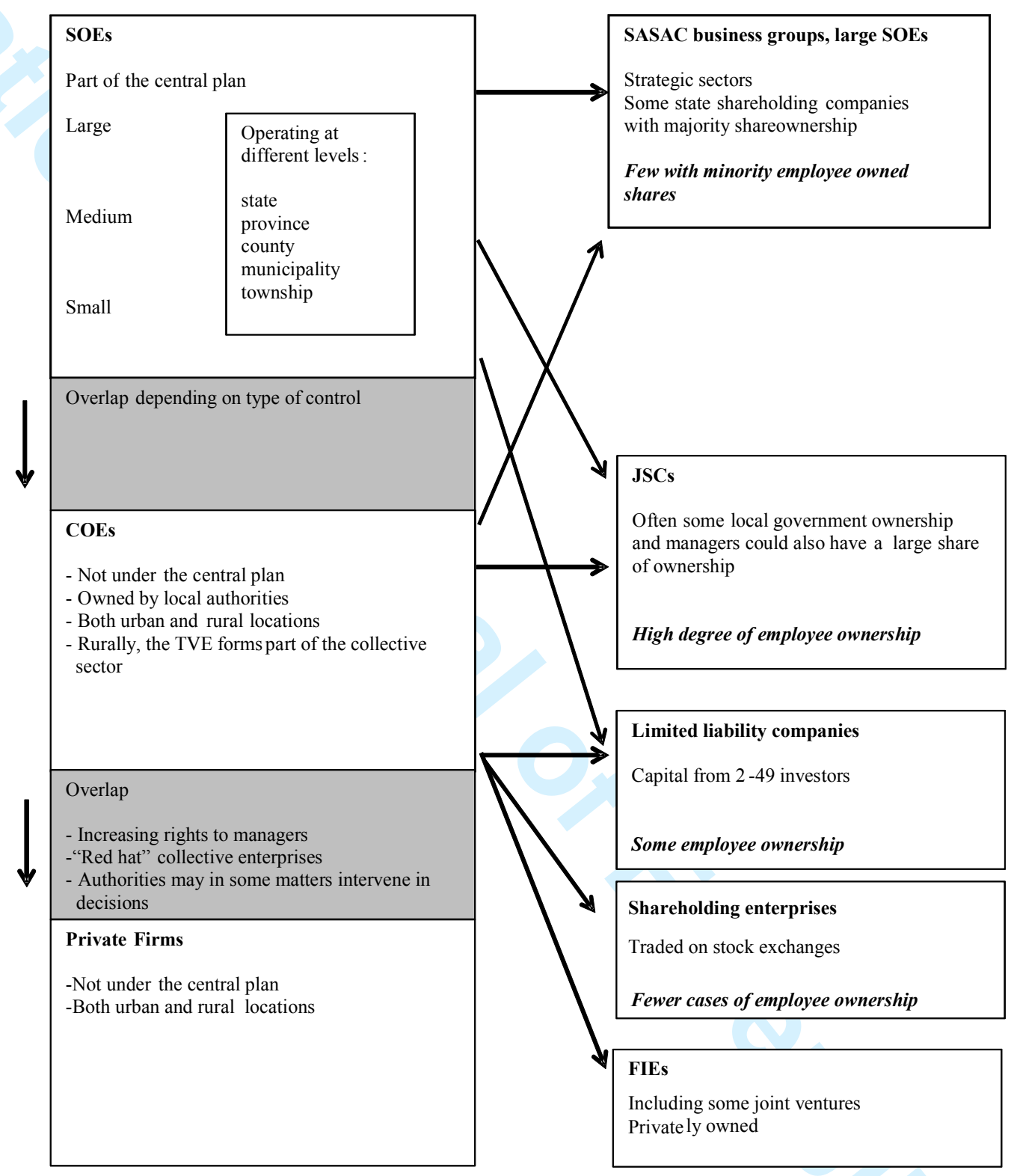


Table 1

Employed persons at year-end by registration status

\begin{tabular}{|c|c|c|c|c|c|c|c|c|c|c|c|c|}
\hline Employed persons - 10,000 & 1991 & 1992 & 1994 & 1996 & 1998 & 2000 & 2002 & 2004 & 2006 & 2008 & 2010 & 2012 \\
\hline Urban employed persons & 15260 & 15630 & 16816 & 19815 & 20678 & 21274 & 24780 & 26476 & 29630 & 32103 & 34687 & 37102 \\
\hline State-owned units & 10664 & 10889 & 11214 & 11244 & 9058 & 8102 & 7163 & 6710 & 6430 & 6447 & 6516 & 6839 \\
\hline Urban collective-owned units & 3628 & 3621 & 3285 & 3016 & 1963 & 1499 & 1122 & 897 & 764 & 662 & 597 & 589 \\
\hline Cooperative units & & & & - & 136 & 155 & 161 & 192 & 178 & 164 & 156 & 149 \\
\hline Joint ownership units & 49 & 56 & 52 & 49 & 48 & 42 & 45 & 44 & 45 & 43 & 36 & 39 \\
\hline Limited liability corporations & & & & - & 484 & 687 & 1083 & 1436 & 1920 & 2194 & 2613 & 3787 \\
\hline Share-holding corporations ltd. & & & 292 & 363 & 410 & 457 & 538 & 625 & 741 & 840 & 1024 & 1243 \\
\hline Private enterprises & 68 & 98 & 332 & 620 & 973 & 1268 & 1999 & 2994 & 3954 & 5124 & 6071 & 7557 \\
\hline Funds from HK, Macao, Taiwan & 69 & 83 & 211 & 265 & 294 & 310 & 367 & 470 & 611 & 679 & 770 & 969 \\
\hline Foreign funded units & 96 & 138 & 195 & 275 & 293 & 332 & 391 & 563 & 796 & 943 & 1053 & 1246 \\
\hline Self-employed individuals & 692 & 740 & 1225 & 1709 & 2259 & 2136 & 2269 & 2521 & 3012 & 3609 & 4467 & 5643 \\
\hline Rural employed persons & 43093 & 43802 & 44654 & 49035 & 49279 & 49876 & 48960 & 48724 & 45348 & 43461 & 41418 & 39602 \\
\hline Township village enterprises & 9609 & 10625 & 12017 & 13508 & 12537 & 12820 & 13288 & 13866 & 14680 & 15451 & 15893 & 16400 \\
\hline Private enterprises & & & & 551 & 737 & 1139 & 1411 & 2024 & 2632 & 2780 & 3347 & 3739 \\
\hline Self-employed individuals & & & & 3308 & 3855 & 2934 & 2474 & 2066 & 2147 & 2167 & 2540 & 2986 \\
\hline Cooperative units* & & & 800 & 726 & - & 930 & 365 & 267 & 265 & 263 & 255 & 252 \\
\hline
\end{tabular}

Source: Statistical Yearbook of China. *Yearbook of China's Township and Village Enterprises 
Table 2 Main publications with evidence on development of employee ownership in China

\begin{tabular}{|c|c|c|c|c|}
\hline publication & $\begin{array}{l}\text { cover } \\
\text { years }\end{array}$ & $\begin{array}{c}\text { source } \\
\text { collected year }\end{array}$ & JSC/privatisation & distribution \\
\hline $\begin{array}{l}\text { Sun } 2002 \\
\text { (Sun 2000) }\end{array}$ & $\begin{array}{l}2000 \\
\text { China }\end{array}$ & $\begin{array}{l}\text { TVE Yearbook } \\
802.000 \text { firms }\end{array}$ & 163.000 JSCs (20\%) & $\begin{array}{l}\text { Managers share high in small JSCs, } \\
\text { Larger include broader groups of } \\
\text { employees to help financing }\end{array}$ \\
\hline Lin \& Zhu 2001 & $\begin{array}{l}1998 \\
\text { China }\end{array}$ & $\begin{array}{l}\text { NBS survey } \\
40,238 \text { Ind. SOEs } \\
3,150 \text { privatised }\end{array}$ & $\begin{array}{l}\text { Some insider shares in } 60 \% \\
\text { of restructured SOEs } \\
16 \% \text { restr. SOEs ->JSCs }\end{array}$ & $\begin{array}{l}\text { No employee shares in } 20 \% \text { of JSCs } \\
\text { JSCs most frequent in small firms }\end{array}$ \\
\hline $\begin{array}{l}\text { Garnaut, Song \& } \\
\text { Yao } 2006\end{array}$ & $\begin{array}{l}\text { 1995-2002 } \\
\text { China }\end{array}$ & $\begin{array}{l}\text { Survey } 683 \\
\text { city SOEs } \\
2002\end{array}$ & $\begin{array}{l}380 \text { were restructured } \\
\text { Employee shares in } 103, \\
\text { large variation } \\
53 \% \text { lim. liability, } 34 \% \text { JSC }\end{array}$ & $\begin{array}{l}\text { private shares } 4 \%->33 \% \text { of which: } \\
10 \% \text { employees } \\
10 \% \text { management } \\
13 \% \text { outsiders }\end{array}$ \\
\hline $\begin{array}{l}\text { Guo, Gan \& Xu } 2008 \\
\text { Guo, Gab \& Xu } 2010\end{array}$ & ${ }_{\text {China }}^{-2005}$ & $\begin{array}{l}\text { Survey } 2935 \text { incl. } \\
717 \text { privatised } \\
2006\end{array}$ & \begin{tabular}{|l} 
Privatization peak \\
$2000-2001$ \\
$63 \%$ of SOEs + COEs \\
privatized by 2005 \\
\end{tabular} & $\begin{array}{l}\text { MBOs in } 47 \% \text { of privatized firms } \\
10 \% \text { to employees, often pressure } \\
22 \% \text { to outsiders, often state related }\end{array}$ \\
\hline & & & & \\
\hline $\begin{array}{l}\text { Vermeer } 1995 \\
\text { Vermeer } 1999\end{array}$ & $\begin{array}{l}1995 \\
\text { Shandong } \\
\text { Hebei }\end{array}$ & $\begin{array}{l}159 \text { Interviews } \\
\text { in } 36 \text { firms }\end{array}$ & \begin{tabular}{|l} 
High variation in \\
privatization methods and \\
distribution of shares
\end{tabular} & \begin{tabular}{|l}
$24 \%$ to employees \\
$18 \%$ to managers \\
$51 \%$ local, but falling over time
\end{tabular} \\
\hline Whiting 1999; 2000 & $\begin{array}{l}\text { 1991-99 } \\
\text { Shanghai } \\
\text { Jiangsu } \\
\text { Zhejiang }\end{array}$ & $\begin{array}{l}252 \\
\text { interviews }\end{array}$ & $\begin{array}{l}\text { High variation between } \\
\text { locations } \\
\text { JSC } 46 \% \text { of output } 1994 \text { in } \\
\text { Yueqing county, Zhejiang }\end{array}$ & $\begin{array}{l}\text { Most JSCs are manager dominated } \\
\text { "Red hat" type to get lower tax and } \\
\text { access to loans }\end{array}$ \\
\hline Li \& Rozelle 2000 & $\begin{array}{l}\text { 1994-97 } \\
\text { Jiangsu } \\
\text { Zhejiang }\end{array}$ & \begin{tabular}{|l} 
Survey \\
168 firms \\
1998
\end{tabular} & 88 privatised & $\begin{array}{|lr|}\text { average } & 1994-1997: \\
\text { employees } & 4 \%->22 \% \\
\text { managers } & 11 \%->48 \%\end{array}$ \\
\hline Li \& Rozelle 2003 & $\begin{array}{l}\text { 1994-99 } \\
\text { Jiangsu } \\
\text { Zhejiang }\end{array}$ & $\begin{array}{l}\text { Survey } \\
670 \text { firms } \\
1998-2000\end{array}$ & $\begin{array}{l}\text { Most TVEs privatized } 1999, \\
\text { high variation in speeds } \\
92 \% \text { to insiders }\end{array}$ & $\begin{array}{l}22 \% \text { to employees } \\
70 \% \text { to managers by end of } 1999\end{array}$ \\
\hline $\begin{array}{l}\text { Dong, Putterman \& } \\
\text { Unel } 2006\end{array}$ & $\begin{array}{l}\text { 1994-2001 } \\
\text { Nanjing, } \\
\text { Jiangsu }\end{array}$ & $\begin{array}{l}\text { Survey Industrial } \\
60 \text { SOEs } \\
10 \text { Urban COEs } \\
\text { 95TVEs 2002 }\end{array}$ & $\begin{array}{l}\text { SOEs }>5 \text { JSCs } 1998-2001 \\
\text { U.COEs }>3 \text { JSCs 1998-2001 } \\
\text { TVEs }>23 \text { JSCs 1998-2001 }\end{array}$ & \begin{tabular}{|c|} 
Employees: $22 \%->34 \%$ in Urban \\
\\
$18 \%->16 \%$ in Rural \\
Managers $\quad 42 \%->37 \%$ in urban \\
$53 \%->61 \%$ in rural
\end{tabular} \\
\hline Tseo et al 2004 & $\begin{array}{l}\text { 1994-2000 } \\
\text { Shandong }\end{array}$ & $\begin{array}{l}\text { Survey } 55 \text { firms } \\
\text { With deeper } \\
\text { ownership data } \\
\text { In Zhusheng (12) } \\
\text { and Qingdao (8) }\end{array}$ & $\begin{array}{l}\text { 1994-2000 } \\
\text { Z-12 employees stable } 73 \% \\
\text { while managers } 20 \%->25 \% \\
\text { Q-6: employee } 76 \%->68 \% \\
\text { Q-2: manager double own. }\end{array}$ & $\begin{array}{l}\text { Most of } 55 \text { firms followed standard: } \\
70 \% \text { of shares to employees, } \\
20 \% \text { of shares to managers }\end{array}$ \\
\hline Oi 2005 & $\begin{array}{l}\text { 1994-2000 } \\
\text { Coastal } \\
\text { provinces } \\
+ \text { Henan }\end{array}$ & $\begin{array}{l}\text { Survey } 451 \text { firms } \\
\text { in } 5 \text { cities } \\
2000-2004\end{array}$ & $\begin{array}{l}\text { JSC favored 1995-96 } \\
\text { large lim. liability with } \\
\text { some state shares, } \\
\text { among smaller more JSCs }\end{array}$ & $\begin{array}{l}\text { Employees more shares early stages, } \\
\text { later: employees turns negative, } \\
\text { while manager go for higher shares } \\
\text { State still majority in large firms }\end{array}$ \\
\hline $\begin{array}{l}\text { Dong, Bowles \& Ho } \\
\text { 2002; 2002b, } 2003\end{array}$ & $\begin{array}{l}\text { 1999-2000 } \\
\text { Jiangsu } \\
\text { Shandong }\end{array}$ & $\begin{array}{l}\text { Survey } 45 \text { TVEs } \\
39 \text { privatized } \\
2001\end{array}$ & $\begin{array}{l}\text { In } 30 \% \text { of cases not real } \\
\text { privatization, only in name }\end{array}$ & $\begin{array}{l}18 \% \text { employee share; managers } 77 \% \\
\text { large profitable firms with high price } \\
=>\text { higher employee share }\end{array}$ \\
\hline Zhang 2008 & $\begin{array}{l}2001-02 \\
\text { Jiangsu } \\
\text { Zhejiang }\end{array}$ & $\begin{array}{l}100 \text { stakeholder } \\
\text { Interviews } \\
2001-2002\end{array}$ & $\begin{array}{l}\text { Different approaches to } \\
\text { privatization depending on } \\
\text { stakeholder powers }\end{array}$ & $\begin{array}{l}\text { Employees got a share if process of } \\
\text { privatisation transparent, Wenzhou; } \\
\text { to managers if manipulated, Wuxi }\end{array}$ \\
\hline
\end{tabular}


Figure 3

Employee ownership in China: the associated drivers and barriers

\section{Societal level}

1. Institutions supporting employee ownership:

a) Gradual political shift favouring more market-oriented enterprises

b) Employee ownership a temporary vehicle for first-stage management takeovers

c) Lack of access to capital meant the acceptance of employee investment

d) Some advantages for employee shares at local levels in some locations, depending on prevalent constellations of power.

e) Dominance of insider privatisation in small- and medium-sized enterprises connected to privatisation advantages and barriers for external investors

\section{Rules for entry/exit of employee owners:}

In general, legislation did not include rules to protect broad-based majority employee ownership

\section{The labour market, risk and conditions for unemployment:}

Risk of unemployment may have influenced the employees' decision to acquire shares

\section{Company level}

1. Collective decision problem increases with size, diverse labour, organisational complexity:

JSCs developed in relatively small manufacturing firms

\section{Capital intensity of the firm:}

Managers took the smallest and cheapest enterprises. When the required capital was beyond their means they needed to include contributions from the broader employee group

\section{Knowledge intensity of the firm:}

No evidence found for greater employee share participation in more knowledge-intensive companies

Often an unequal distribution of shares with managers and key employees receiving the bulk of them

\section{$\underline{\text { Individual level }}$}

\section{Employee resources:}

In many cases, employees could afford a relatively large capital contribution because of the high household savings rate

\section{Desire for self-governance:}

Capital gains or job security were the main motives behind ownership for employees, not economic democracy or self-governance. 